\title{
РЕАЛІЗАЦІЯ ІМПЕРАТИВНОЇ МОДАЛЬНОСТІ В ІНФІНІТИВНИХ КОНСТРУКЦІЯХ
}

У пропонованій статті розглянуто актуальне для сучасної лінгвістики питання специфіки інфінітивних конструкцій з огляду на природу втіленого в них імперативного модального значення. Вказано на граматичні особливості иъвого типу речень та їх функційно-семантичну своєрідність. Здійснено спробу пояснити зумовленість вираження категоричного волевиявлення за допомогою інбінітивного предиката. Запропоновано приклади реалізачії названих конструкиій у різних комунікативних сферах.

Ключові слова: імператив, імперативна модальність, інфінітив, інфінітивне речення, імперативна інфінітивна конструкція.

Umrykhina L. V. The Realization of the Imperative Modality in the Infinitive Structures. The variety of approaches to compilation of the imperative, the ambiguity of the interpretation of its semantics and the numerous terminological differences determine the relevance of a detailed study of the imperative infinitive structures as a marker of imperative modal meaning.

The proposed article deals with the issue of the specificity of the infinitive structures, which is relevant for modern linguistics, in view of the nature of the imperative modal meaning. The purpose of the article is to identify the semantic-functional uniqueness of imperative infinitive sentences as a specialized type of syntactic constructs intended to express a prototype imperative meaning. Some grammatical features of this type of sentences, their functionally-semantic peculiarities are indicated. An attempt to explain the interdependence of the expression of the categorical will by the means of infinitive predicate was made. Examples of implementation of the mentioned constructions in different communicative spheres are offered.

The imperative infinitive sentences are a specialized type of syntactic constructs designed to implement an imperative in its prototype meaning. The construction of infinitive sentences corresponds to the semantic essence of the imperative: an independent infinitive expresses the categorical expression of the speaker's perception of the action, defined as subjectively necessary, obligatory, and requiring a compulsory execution. The semantic predictability of the grammatical form of infinitive structures correlates with the specifics of their functional purpose. Infinitization results in the formation of a strong expressive form of volition, as effective as possible for the implementation of the communicative model of «order-command-obedience».

The prospect of further research is the analysis of imperative constructions in view of identifying the functional features of other structural types.

Key words: imperative, imperative modality, infinitive, infinitive sentence, imperative infinitive structure. 


\section{Вступ}

Сучасний період розвитку мовознавства позначений посиленою увагою до проблем семантики і синтаксису, у сфері яких перебувають питання відображення в мові найскладніших людських феноменів. Одним із найважливіших завдань у дослідженні синтаксису $є$ поглиблене вивчення модально орієнтованих конструкцій як репрезентантів складної взаємодії мови й людського мислення. Незважаючи на значний науковий інтерес до природи спонукальності, досі немає комплексного структурно-семантичного аналізу спонукальних конструкцій із чітким розмежуванням усіх їх видів, зокрема виокремленням серед них власне імперативних як реалізаторів своєрідного семантичного змісту. Потрактування імперативних конструкцій у сучасному мовознавстві позначено численністю підходів до вивчення, термінологічними розбіжностями й неоднозначними інтерпретаціями. Актуальним залишається дослідження функційно-семантичної різноманітності імперативних конструкцій, установлення залежності між їньою структурою, семантикою, комунікативно-функційним потенціалом. Із огляду на це заслуговують на окремий розгляд імперативні інфінітивні конструкції як один із центральних типів репрезентації суб'єктивно-модального значення імператива.

До розроблення проблем імперативних конструкцій у різних аспектах висвітлення звертались А. П. Володін (Храковский \& Володин, 1986), Н. В. Головіна (Головіна, 1997), В. Ю. Гусєв (Гусев, 2013), О. Л. Даскалюк (Даскалюк, 2006), В. С. Храковський (Храковский \& Володин, 1986), Н. В. Швидка (Швидка, 1998) та інші. Досі триває дискусія щодо місця інфінітивних речень у системі модально орієнтованих конструкцій, визначення їхнього граматичного й семантичного статусу.

Метою статті є виявлення функційно-семантичної специфіки імперативних інфінітивних речень як спеціалізованого типу синтаксичних конструкцій, призначених для вираження імперативного значення.

\section{Методи й методики дослідження}

У роботі використано описовий, трансформаційний методи, а також методи зіставлення й компонентного аналізу. Методика дослідження - аналіз мовного явища від рівня комунікативного, на якому формується модальне значення через його семантико-синтаксичну 
реалізацію, до рівня синтаксичного, де виявляються засоби формального та семантичного вираження імперативної модальності.

Прийнятий погляд на імператив як суб'єктивно-модальне значення, суттю якого є уявлювана, проте передбачувана (ірреальнопотенційна) ситуація, на реалізації якої акцентує мовець (суб’єкт волевиявлення), каузуючи ії засобом апелювання (безпосереднього звернення) до адресата (потенційного виконавця).

\section{Результати та дискусії}

Спеціалізованим типом синтаксичних конструкцій, своєрідним маркером імперативної модальності $є$ інфінітивні речення - односкладні конструкції із синтаксично незалежним інфінітивом у функції предиката. Їхня особливість - у семантичній передбачуваності граматичної форми. Імперативність, як слушно зауважує Т. В. Шмельова, створюється самим фактом наявності інфінітива в предикативній основі (Шмелева, 1980 : 137). Серед основних функцій інфінітива вчені якнайперше називають вираження імперативного значення, а саме безапеляційного наказу, категоричної постанови, розпорядження (Виноградов, 1972 : 459), а речення з інфінітивним предикатом визначають як наказові (не спонукальні) (Пешковский, 2001 : 382) або імперативні (Реформатский, 1996 : 179).

Реалізацію модального значення імператива засобом незалежного інфінітива вважають історично визначеним мовним явищем. Будучи однією із найдавніших мовних форм, так званий імперативний інфінітив має свою функційно-семантичну зумовленість. Розвинувшись на грунті віддієслівного іменника, інфінітив закріпився в дієслівній системі праслов'янської мови й отримав специфічне призначення - виражати імперативну семантику, що пов'язано з потребою оформлення категоричного наказу (Мельничук, 1966 : 101). Використання імперативних інфінітивних конструкцій, що їх пізніше буде виокремлено як інфінітивні речення (передусім завдяки працям О. М. Пєшковського), первинно пов'язане з потребою оформлення державно-правових документів. Дослідницькі роботи у сфері вивчення староукраїнських писемних пам'яток засвідчують широке використання інфінітивних конструкцій у функції конкретних указівок щодо необхідності й обов'язковості виконання певної дії, короткого й чіткого переліку обов'язків і прав юридичної особи тощо. 
Інфінітив в імперативних конструкціях має чітке соціальне маркування: «Його вживання є нормативним у мовленні керівника, а не в ролі підлеглого, тобто конструкції такого виду трапляються переважно у діловій та епістолярній літературі староукраїнської мови: грамотах, листах, інструкціях, резолюціях, наказах» (Шевчук, 2008 : 79). Недарма інфінітиву першочергово приписують роль основного засобу вираження модального значення імператива. Саме інфінітивна форма якнайточніше відбиває первинну сутність вираження наказу - беззаперечно категоричного вияву спонукання - прерогативи володаря, імператора (лат. imperator - володар). Повноваженням наказувати, повелівати може бути наділений лише володар, повелитель - особа, традиційно усвідомлювана як така, що повеліває, наказує за правом своєї влади, як-от: монарх, правитель, князь. Очевидна взаємозумовленість двох смислових компонентів імператива, пов'язаних із наказовістю і владою, закріплена й у визначенні вихідних лексем, етимологічно споріднених із терміном «імператив»: imperativus - лат. наказовий, владний, impero - лат. наказую, володарюю, imperator лат. володар. Механізм вираження імперативного значення й створення відповідного імперативного ефекту засобом інфінітивних конструкцій спирається на домінанту семантичну рису «наказовість», що пов'язано, насамперед, із ситуацією повеління. Історично зумовлена зміна соціальних ролей мовців сприяла зменшенню активності використання цієї форми наказовості в широкій комунікації.

Залишаючись продуктивним у плані вираження імперативної модальності типом синтаксичних конструкцій, інфінітивні речення вирізняються своєрідністю структурно-семантичної організації. Із формально-граматичного боку для таких речень характерна наявність одного головного члена, а з семантичного - вони є двокомпонентними, оскільки передбачають обов'язкову наявність суб'єкта і предиката. Загальна семантика інфінітивних речень з імперативним значенням має таку структуру: суб'єкт - його дія, зумовлена чиєюсь волею й усвідомлювана як необхідна, обов'язкова. Інфінітивна конструкція, використана в умовах прямого волевиявлення, маніфестує потребу в реалізації певного факту ірреальної дійсності, наявного на момент мовлення лише у свідомості адресанта. Відповідно до його задуму пропозиційний зміст створеного висловлення повинен у результаті отримати повний збіг із ситуацією реальної дійсності. 
В імперативному реченні типу Стояти! закладено семантико-граматичні передумови інтерпретації пропозиційного змісту висловлення з орієнтацією на потенційність виконання адресатом затребуваної дії як Ти стоїш. Семантика будь-якого висловлення зі значенням імператива, виходячи із його основного функційного призначення, відбиває референтну ситуацію апелятивного спілкування, яка передбачає обов'язкову наявність щонайменше двох суб'єктів комунікації, одним із яких $є$ адресат, на якого покладено роль потенційного виконавця названої дії. Тож облігаторними змістовими компонентами імперативного висловлення з інфінітивним предикатом $€$ значення безапеляційного волевиявлення, номінативне значення дії, значення мовця й значення адресата, що дозволяє розтлумачувати сутність імперативного речення Стояти! як Я (мовець) наказую тобі (адресатові), щзоб ти стояв.

Інфінітивні імперативні речення - специфічний тип синтаксичних конструкцій, що мають власну семантику структурної схеми, тому вони не вступають у парадигматичні відношення з іншими інфінітивними реченнями, а реалізуються лише у формі одного ірреального способу. Це винятковий варіант актуалізації імперативності, коли «імперативна семантика виступає як категорійне значення особливих форм (морфологічних і синтаксичних)» (Бондарко, 1990 : 87). Семантика імперативних конструкцій інфінітивного структурного типу зумовлена специфікою їхнього функційного призначення, пов'язаного з потребою беззастережного виконання певної дії. У змісті подібних структур закладено превалюванння вагомості конституента «необхідність» поряд із основними, як-от: ірреальність, потенційність, волітивність, адресованість, апелятивність, каузативність, прескриптивність. Недарма для вираження значення суб'єктивної необхідності також послуговуються інфінітивними конструкціями, як-от у прикладі втілення думок внутрішнього діалогу героя:

Тоді княжич Святослав залишився один у полі; холодне небо вгорі, сірі сніги навкруги, холод на душі і в сериі.

«Гнатись! - вирнула думка. - Повернути ї̈ до города!»

Але одразу ж він, здавалося, почув голос Малуші, ї̈ слова: «Пощо, княжичу, женешся за мною? За чим женешся? Пізно ти за мною погнався, княжичу. Я ж тебе ждала вночі, а ніч минула, все минуло...»

I ие була правда (С. Скляренко). 
Фактична нездійсненність фрагменту картини уявного світу мовця зрозуміла з контексту. Об’єктивні обставини змушують героя поступитися своїми почуттями на користь державного обов'язку. Так, раптовість емоційного сплеску змінюється розважливістю у прийнятті раціонального рішення: Він у годину, коли треба було вибирати між любов'ю й обов'язком, обрав останнє. Адже те, що є потрібним і вкрай необхідним для задоволення душевних потреб закоханого, виявляється абсолютно протилежним за вагомістю відповідно до оцінених ним реалій. Тож представлені у висловленнях ірреальні ситуації залишаються значущими лише на рівні виявлення суб'єктивної необхідності, не набуваючи розвитку в плані майбутньої реалізації. Апелювання до самого себе засобом таких висловлень не означає самоспонукання мовця, а є лише виявом його душевних страждань, пов'язаних із усвідомленням неможливості здійснення необхідного.

Імперативні інфінітивні конструкції, натомість, завжди орієнтовані на конкретний результат. Інфінітивний предикат акумулює в собі максимальну силу категоричного волевиявлення з найбільшою концентрацією ультимативності й безапеляційності. Незважаючи на невід'ємну прив'язку імперативного висловлення до адресата, суб'єкта виконання потенційної дії, інфінітивне речення повністю нівелює фактичність граматичного вираження його особи. На передньому плані - значущість факту реалізованої дії, необхідність якої очевидна для суб’єкта повідомлення. Потенційність реалізації затребуваної ситуації не підлягає сумніву, на думку адресанта, а навіть більше, постає в його власній інтерпретації як обов'язкова для адресата. При цьому фізична здатність і моральна готовність останнього до виконання наказаного залишаються поза межами суб'єктивного сприйняття відправника імперативного висловлення.

У комунікативній сфері інфінітивні конструкції реалізують імперативне значення зі смисловою домінантою категоричності, навіть ультимативності. Ця форма вираження імператива найбільш прийнятна з огляду на конкретність і чіткість вираження думки в плані передачі змісту наказуваного. Зобов'язувальний характер таких висловлень позбавляє реципієнта можливості неоднозначно інтерпретувати почуте. Якщо імперативні висловлення, структуровані за допомогою конструкцій із предикатом у формі дієслова наказового способу другої особи, що також належать до сфери вираження 
категоричного волевиявлення, можуть набувати на виході різноманітних відтінків основного імперативного значення, далекі від ультимативності наказу, як-от: поради, прохання, інструкції, умовляння, заспокоєння, то інфінітивним імперативним конструкціям властива незмінна орієнтованість на абсолютну категоричність. Тому навіть поза межами контексту останні завжди сигналізують про наказ, обов'язковий для виконання. Тож репрезентація пропозиції в реченні через інфінітивізацію визначає категоричність, навіть жорсткість імператива, максимальний вияв його потенціалу.

Наділені потужним імперативним зарядом, що створюється самим фактом наявності інфінітива, аналізовані конструкції органічно вписуються в контекст комунікативної моделі «наказ-веління - послух». Мовне втілення наміру адресанта отримати конкретний результат також потребує конкретності й визначеності. Тому мовець свідомо застосовує силу інфінітивної конструкції, в якій специфіка імперативного значення виявляє максимально чітке й безпосереднє вираження. Як правило, синтаксична структура імперативних інфінітивних конструкцій зведена до мінімуму. Часто це односкладні непоширені речення, у яких предикат акумулює всю імперативноспонукальну силу. Семантичний обсяг дієслова, яким виражений предикат, є тим координаційним центром, що регулює відносини між мовцем та адресатом. Відрізняючись максимально семантичною ємністю й чіткою визначеністю, подібні конструкції спроектовані на ясність сприйняття в комунікативному плані.

Так, із прикладу

\section{- Видобути всіх! Миттю!}

- Зробимо, імператоре, - Заубуш зігнав із себе звичну насмішкуватість, став слухняний $і$ покірливий. - Зробимо все, як звелиш (Б. Загребельний) видно, що імперативне волевиявлення, вербалізоване засобом інфінітивної конструкції, $є$ цілком інформативним для суб’єкта-виконавця потенційної дії. Адекватне сприйняття й швидке реагування свідчать про ефективність використання такого засобу впливу на майбутні вчинки слухача. Синхронне тлумачення висловленого як категоричного наказу з боку обох комунікантів зумовлене сприятливим для цього соціально-комунікативним фоном спілкування. Очевидними є традиційність і загальноприйнятість для представників тогочасного суспільства такого стилю мовленнєвої поведінки, 
за якого статус адресата зведено до ролі пасивного сприймача й покірного виконавця наказуваного.

У прикладі

- Лучників! - побілілими очима втупився в нього Генріх, щойно Заубуш з'явився в дверях. - Розставити в замковому дворі, на мурах, на вежах лучників і щзоб стріляли голубів, щьоб вибили до єдиного. I довкола палащу, і в Бамберзі, і скрізь, де буду! Бити иих тварюк, ичх жирних, гидких, ворожих...

$<\ldots>$

- Перебити всіх. I щоб не прилітав сюди жоден! Тримати лучників з напнутими тятивами. Таке веління! (П. Загребельний) мовець-імператор застосовує силу інфінітивної форми імператива для реалізації не зовсім звичної для нього й слухача ситуаціі. Тому інфінітивні імперативні конструкції оточені додатковими синтаксичними формами вираження змісту задуманого. Адресант, очевидно, передбачаючи вірогідність комунікативного непорозуміння, підкріплює значущість усіх деталей волевиявлення за допомогою заключного Таке веління!, що маніфестує владний характер висловленого й у такий спосіб запобігає можливості неоднозначного потрактування почутого.

А от приклад використання імперативних інфінітивних конструкцій у мовленнєвій сфері пізнішої історичної доби, пов'язаної iз розвитком українського козацтва, що ілюструє специфіку розподілу комунікативних ролей відповідно до ієрархічної диференціації суб'єктів мовлення, як-от гетьмана й хорунжого:

Юрась кисло скривився.

- А може, й ти? Га?

Многогрішний злякано перехрестився.

- Що ви, пане гетьман!.. Ось вам хрест - я вам найвідданіший слуга! Як пес, ладен кожному вашому недругові горло перегризти!

- Гаразд, гаразд, вірю, - недбало махнув рукою гетьман, а потім, бачачи, як його слова схвилювали хорунжого, додав: - Ти єдиний, на кого я можу покластися...

$<\ldots>$

- Tи схопив їх?

- Без вашого наказу? - здивувався Многогрішний. - Як би я посмів? 
- Схопити злодюг! Негайно! I тримати під посиленою вартою!.. Трохи змічнію - сам говоритиму з ними!

- Буде зроблено, ваша ясновельможність (В. Малик).

Хорунжий, спровокований виявом гетьманської недовіри до себе, настійливо переконує у своїй відданості, запевняючи, зокрема, у готовності до виконання усього необхідного. Висловлений наказ зініційований самим реципієнтом із метою довести власну надійність і покірливість перед авторитетною для нього особою, яка фактично $є$ статусно вищою відповідно до військового козацького рангу. Миттєве реагування комуніканта на непрямий запит віддати наказ, що вербально реалізовано через відповідні імперативні висловлення, свідчить про нормативність функціонування таких інфінітивних конструкцій у світлі ведення військових стратегій. Як видно, відхилення від усталеного сценарію «наказ - послух» перешкоджає успішному перебігу запланованих акцій.

Незважаючи на крайню дієвість інфінітивних конструкцій у плані вираження змісту волевиявлення, соціально визнаним сьогодні $€$ неприйнятність використання такої жорсткої імперативної форми. Сучасний світ спілкування вимагає нової моделі поведінки, абсолютно позбавленої рис імперської комунікації. Несучи на собі печать владності, інфінітивні імперативні конструкції генетично знижують рівень індивідуальної статусності співрозмовника, позбавляючи його привілею самостійно вирішувати долю майбутнього перебігу ситуації, яка безпосередньо стосується також і його особистості. Інакше, використовуючи таку жорстку імперативну форму, мовець ставить себе вище за співбесідника, опускаючи його на більш низьку статусну позицію. У світлі сучасної комунікації адресантові необхідно зважати на соціально-етикетний бік мовлення, ураховувати свободу волі адресата, виявляючи пошану до співрозмовника. Якщо у разі використання імперативної конструкції типу Bстань! існує можливість супутнього синтаксичного оточення різноманітними засобами прояву ввічливого ставлення до адресата, наприклад: Bcmaнb, будь ласка!; Устань, друже!, Прошу, встань!, то конструкція типу Встати! позбавлена легкості пом'якшувати категоричність і жорсткість наказу.

Історична традиція застосування семантично ємної й комунікативно влучної форми волевиявлення залишила відбиток у сучасній практиці діловодства. Право віддавати накази та розпорядження 
за допомогою аналізованого типу конструкцій сьогодні належить особі начальницького складу, яка може письмово зафіксувати директивні висловлення, структурувавши їх за допомогою соціально прийнятих мовних кліше. Використання таких імперативних конструкцій в усній інтеракції «начальник - підлеглий» $є$ неприйнятним для мовленнєвої поведінки сучасного керівника й належить до комунікативних девіацій. Єдиною сферою сучасного спілкування, де такі конструкції залишаються нормативними й органічними, $є$ арена військових команд, наказів і розпоряджень. Висловлені коротко, чітко й владно, такі мовленнєві форми якнайкраще відповідають меті їх застосування, що пов'язано із затребуваним результатом безальтернативного й швидкого виконання конкретної дії.

У військовому мовленнєвому арсеналі існує цілий набір усталених імперативних форм типу чітко зафіксованих статутом команд Покласти зброю! Вийти зі строю! Багнет - відімкнути! Вартовий, прийняти пост! До них логічно віднести такі ілюстрації із мови художніх творів: - Встати! - крикнув командир. - Вперед!!! (О. Довженко); - Розложити огонь, - наказав Дрозд (А. Чайковський); Після скомандував: "Тим, хто не бажає приймати присягу - вийти зі строю на три кроки» (А. Карпенко). Окрім цього, військові послуговуються імперативними інфінітивними конструкціями для формулювання необхідних волевиявлень, зміст яких не належить до мовних кліше. Об'єктивні обставини, пов'язані зі специфікою військової справи, вимагають миттєвого реагування на мовленнєвий запит і термінового виконання конкретної дії, часто життєво необхідної. Утілення військового імператива в мовному значенні інфінітивної форми можна вважати свідченням релевантності історично обраного типу конструкцій для досягнення відповідної комунікативної мети. Наприклад,

- Старшина...

- Я!

- Негайно очистити вози від усвого стороннвого. Викидати геть усе, щзо не може стріляти або вибухати. Натомість довантажитись боєприпасами.

- Слухаюсь! (О. Гончар);

- Спішитись і покласти зброю на землю!

- Свої! - озвався Микола. 
- Може, ти ще накажеш і нам самим полягати?

- Покладіть зброю! Я кому сказав?

Коли наказ було виконано, Гупало виїхав на просіку і зіскочив 3 коня (В. Шкляр).

\section{Висновки}

Імперативні інфінітивні речення є спеціалізованим типом синтаксичних конструкцій, призначеним для втілення імператива у його прототипному значенні. Побудова інфінітивних речень якнайкраще відповідає семантичній сутності імператива: незалежний інфінітив виражає категоричне волевиявлення мовця щодо здійснення дії, визначеної як суб'єктивно необхідна, потрібна, обов'язкова й така, що потребує безапеляційного виконання. Семантична передбачуваність граматичної форми інфінітивних конструкцій корелює зі специфікою ï функційного призначення. Інфінітивізація зумовлює утворення жорстокої форми волевиявлення, максимально ефективної для реалізації комунікативної моделі «наказ-веління - послух». Перспективним постає подальше дослідження імперативних конструкцій у плані виявлення особливостей функціонування інших структурних типів.

\section{ЛІТЕРАТУРА}

1. Бондарко А. В. Теория функциональной грамматики. Темпоральность. Модальность. Ленинград: Наука, 1990. 264 с. 2. Виноградов В. В. Русский язык: Грамматическое учение о слове. Москва: Высшая школа, 1972. 614 с. 3. Головина Н. В. Семантика императива и способы его выражения в современном русском и английском языках: дисс. ... канд. филол. наук: 10.02.20. Москва, 1997. 186 с. 4. Гусев В. Ю. Типология імператива. Москва: Языки славянской культуры, 2013. 336 с. 5. Даскалюк О. Л. Семантико-граматична характеристика імператива сучасної української мови: дис... канд. філол. наук: 10.02.01. Чернівці, 2006. 206 с. 6. Мельничук О. С. Розвиток структури слов'янського речення. Київ: Наукова думка, 1966. 322 с. 7. Пешковский А. М. Русский синтаксис в научном освещении. Москва: Языки славянской культуры, 2001. 510 с. 8. Реформатский А. А. Введение в языковедение / науч. ред. В. В. Виноградов. Москва: Аспект Пресс, 1996. 536 с. 9. Храковский В. С., Володин А. П. Семантика и типология императива. Русский императив. Ленинград: Наука, 1986. 272 с. 10. Швидка Н. В. Імперативні речення в сучасній українській мові: семантика, засоби вираження спонукальності, функції: дис. ... канд. філол. наук: 10.02.01. Слов'янськ, 1998. 172 с. 11. Шевчук I. Імператив у односкладних реченнях староукраїнської мови. Волинь-Житомирщина. Історико-філологічний збірник з регіональних проблем. 2008. Випуск 16. С. 77-84. 12. Шмелева Т. В. Пропозиция и ее репрезентации в предложении. Проблемы теории и истории русского языка / ред. К. В. Горшкова. Москва: Изд-во Моск. ун-та, 1980. С. 131-137. 


\section{REFERENCES}

1. Bondarko, A. V. (1990). Teorija funkcionalnoi gramatiki. Temporalnost. Modal'nost. [Theory of functional grammar. Temporality Modality]. Leningrad: Nauka [in Russian]. 2. Vinogradov, V. V. (1972). Russkij jazyk: Grammaticheskoe uchenie o slove. [Russian language: The grammatical doctrine of the word]. Moskva: Vysshaja shkola [in Russian]. 3. Golovina, N. V. (1997). Semantika imperativa i sposoby jego vyrazhenija v sovremennom russkom I anglijskom jazykah. [The semantics of the imperative and ways to express it in modern Russian and English]. Candidate's thesis. Moskva: MPU [in Russian]. 4. Gusiev, V. Ju. (2013). Tipologija imperativa. [Typology of the imperative]. Moskva: Yazyki slavianskoi kultury [in Russian]. 5. Daskaliuk, O. L. (2006). Semantyko-gramatychna harakterystyka imperatyva suchasnoji ukrajins'koji movy. [Semantic-grammatical characteristic of imperative of modern Ukrainian language]. Candidate's thesis. Chernivtzi: ChNU im. Yuriia Fedkovycha [in Ukrainian]. 6. Mel'nychuk, O. S. (1966). Rozvytok struktury slovianskoho rechennia. [Development of the structure of the Slavic sentence]. Kyiv: Naukova dumka [in Ukrainian]. 7. Peshkovskiy, A. M. (2001). Russkiy sintaksis v nauchnom osveshenii. [Russian syntax in scientific coverage]. Moskva: Jazyki slavianskoi kultury [in Russian]. 8. Reformatskiy, A. A. (1996). Vvedenie v jazykovedenie. [Introduction to Linguistics]. Moskva: Aspekt Press [in Russian]. 9. Hrakovskij, V. S., \& Volodin A. P. (1986). Semantika i tipologija imperativa. Russkij imperative. [Semantics and typology of the imperative. Russian imperative.] Leningrad: Nauka [in Russian]. 10. Shvydka, N. V. (1998). Imperatyvni rechennia v suchasnij ukrajins'kij movi: semantyka, zasoby vyrazhennia sponukal'nosti, funktciji. [Imperative sentences in modern Ukrainian language: semantics, means of expression of induction, functions]. Candidate's thesis. Sloviansk: Slovianskyi derzh. ped. in-t [in Ukrainian]. 11. Shevchuk, I. (2008) Imperatyv u odnoskladnyh rechenniah staroukrainskoi movy. [The imperative in the single-composition sentences of the Old Ukrainian language]. Volyn-Zhytomyrshchina. Istoryko-filolohichnyi zbirnyk z rehionalnyh problem - Volyn-Zhytomyr region. Historical and philological collection on regional problems, 16, 77-84 [in Ukrainian]. 12. Shmeliova, T. V. (1980). Propozictia i eje reprezentatsii v predlozhenii. [Proposition and its representations in a sentence]. Problemy teorii i istorii russkoho iazyka - Problems of the theory and history of the Russian language, (pp. 131-137). Moskva: Izdatel'stvo Moskovskoho universiteta [in Russian].

Умрихіна Любов Володимирівна - кандидат філологічних наук, доцент, докторант кафедри української мови, Харківський національний педагогічний університет імені Г. С. Сковороди. Вул. Валентинівська, 2, м. Харків, 61168, Україна.

Тел.: +38-096-29-19-423

E-mail: lubovumrikhina@gmail.com

orcid.org / 0000-0003-3888-342X

Umrykhina Liubov Volodymyrivna - PhD in Philology, Doctoral Student, Ukrainian Language Department, H.S. Skovoroda Kharkiv National Pedagogical University. Valentynivska Str., 2, Kharkiv, 61168, Ukraine.

Надійшла до редакції 26 травня 2019 року 